\title{
Brazilian franchisor: Entry and operation of internationalized franchise
}

\author{
Helder de Souza Aguiar ${ }^{1 A}$, Marcos Roberto Luppe ${ }^{B}$, and Paulo Tromboni de Souza Nascimento ${ }^{B}$ \\ ${ }^{A}$ Universidade Anhembi-Morumbi - UAM, São Paulo, SP, Brazil \\ ${ }^{B}$ Escola de Artes, Ciências e Humanidades da Universidade de São Paulo, EACH/USP, SP, São Paulo, Brazil
}

ARTICLE DETAILS
Article history:
Received: February $28^{\text {th }}, 2017$
Accepted: October $03^{\text {th }}, 2017$
Available online: November $11^{\text {th }}, 2017$
Double Blind Review System
Scientific Editor
Mariana Sutter

\section{Keywords:}

Franchising

International Operation

Entry Mode

Franchisors

Internationalization

\begin{abstract}
This study aimed to compare the entry and operations strategies of franchisors of developed countries into foreign countries with Brazilian counterparts. Were there significant differences? An exploratory study was conducted with 16 international franchisors operating in Brazil and 31 Brazilian franchisors operating abroad. The results show that international franchisors operating abroad prefer to use a subsidiary in the destination country. At the same time, this strategy is little used by Brazilian franchisors, which prefer the strategy of direct franchises. For data collection, 47 directors or managers of the international expansion of Brazilian companies and the expansion directors of the international companies which operates in Brazil were interviewed. Although more expensive, the subsidiary in the target country offers greater control over the expansion of business reducing the problems caused by the distance of the country of origin. For the management of franchisors, this paper points out that the subsidiary is a natural evolution of entry and operation mode when it is desired or it is needed to control the expansion of networks in other countries. Thus, managers of franchisors in emerging countries should carefully examine the subsidiary option in the target country when their company considers accelerating international growth.
\end{abstract}

(c) 2017 Internext | ESPM. All rights reserved!

\section{INTRODUCTION}

Since the 1970s, many studies have sought to explain the international expansion of the franchising industry in developed countries (Brookes \& Roper, 2011; Elango, 2007; Goncalves \& Duarte, 1994; Hackett, 1976). Recently, studies began to emerge about franchisors seeking opportunities in emerging economies and they show that these markets are growing rapidly. International franchisors have stepped up investment in these countries (Baena, 2012; Welsh, Alon, \& Falbe, 2006). There are also a considerable number of franchises from emerging countries that are launching in international markets (Aguiar, Consoni, \& Bernardes, 2014; Thomas, 2013).

Late internationalization of those franchisors from emerging countries such as Brazil may raise different practices and trends that are found in franchisors of developed markets. A significant difference lies in the fact that in developed markets such as the US, the international movement of franchises is mature, having existed for more than 40 years (Hackett, 1976). Franchise internationalization in emerging markets is recent and only intensified in the early 2000s. Most emerging countries go through a process of opening their borders to increased international trade flow and investments (Khanna \& Palepu, 2010). China, India, Mexico and Brazil are important emerging markets. The understanding in regards to the franchise internationalization companies from emerging markets needs to be strengthened. However, the emerging countries since the early 1990s have shown significant growth in franchise sectors in their domestic markets (Welsh \& Avenue, 2006). 
Evidence from different parts of the world shows franchising internationalization in the emerging economies (Thomas et al. 2013). Emerging economies are defined as countries in the process of structural reforms and rapid economic growth (as measured by gross domestic product per capita), but are still behind the developed economies.

There are abundant examples of franchises in emerging countries who sought internationalization. The Argentinean companies Freddo and Havanna, who specialize in candies and milk ice cream, have a strong presence in Latin America and more recently started operating in countries like the United States and England. Pardo's Peruvian Chicken, which has franchises in Chile, United States and Brazil. According to the ABF (Brazilian Association of Franchising), in 2016, the country ended the year with 138 brands active in other markets (ABF, 2017). Amongst the largest players in the sector in the world, by number of domestic units, five emerging countries are most prominent: China, India, Philippines, Brazil and Mexico and in number of brands Brazil is fourth behind only of China, South Korea and U.S.A. (ABF, 2017).

Studies of international franchise expansion are interesting for both academics and executives. Aliouche and Schlentrich, (2011) are emphatic that executives are frustrated by the lack of tools to decide when the company starts planning with a view to internationalization.

Brazilian franchises use different entry modes in international markets, such as own units, direct franchises, master franchises or joint ventures, and the choice of one or another is related to levels of control, international strategies and investments abroad (Aguiar, Consoni, \& Bernardes, 2014b). In this way, this study seeks to analyze the entry and the operation methods of Brazilian companies when they internationalize, and contrast them with the way international companies operating in Brazil perform their management. In addition, we sought to investigate the levels of control and investment in the executives' views that participated in the study.

This paper analyzes if the maturity of the internationalization of the companies changes the way of operating, taking into account that the internationalization of Brazilian franchises is still in an initial stage. The intention is to broaden the discussion of other papers that looked at how the companies operated the strategy in their first internationalization (Burton \& Cross, 1995; Aguiar, Consoni, \& Bernardes, 2014; Aliouche \& Schlentrich, 2011; Camargo, Rocha, \& Silva, 2016; Jell-ojobor \& Windsperger, 2013; Khauaja \& Toledo, 2011; Quinn \& Alexander, 2002; Rocha, Borini, \& Spers, 2012).

Brazilian franchises use different modes of entry in international markets, such as Franchisee-owned, Franchises directly, Master Franchises or Joint Ventures, and the choice of one or the other is related to levels of control, international strategies and investments abroad. (Melo, Borini, Oliveira Jr., \& Parente, 2015).

The time to launch the internationalization of franchising in emerging countries compared to the internationalization in developed countries was the chosen point for this research subject - analysis of chains operating in Brazil compared to the Brazilian companies that operate abroad. The main contribution of this study lies in the possibility that both academics and managers in franchising companies can note a phenomenon already experienced by marketing networks longer involved with internationalization movements. Special emphasis is placed on companies in the franchising market in emerging countries. The findings may lead to a pattern that can be used as a tool, so companies can prepare strategically for the future of their operations based on models already tested and approved. To prepare this qualitative and exploratory study, we have used a semi-structured script applied to directors of brand expansion of franchises with operations in Brazil, domestic and international, of which 47 were identified. The sample has 31 Brazilian franchises and 16 international franchises.

In the next section, we will synthesize existing views on international expansion franchises. In third section, we will present the research methodology. In fourth section, we will present the results. Finally, we will discuss the implications of our findings.

\subsection{Franchise internationalization}

The franchise is, above all, an expansion operation that seeks rapid growth with investments and highly engaged partners in the business (Gonzalez-diaz \& Solis-rodriguez, 2012). The agency theory proposed by Jensen and Meckling (1976) was taken into account by Lafontaine (1992) when she proposed that monitoring and controlling franchised units may be cheaper than managing own units with managers or managing partners. This principle is based on the 
issue of the franchisee having differentiated incentives, where he is the owner of the unit that will manage, which differs from the managers who are hired. In addition, they are remunerated only by their unit, unlike managing partners who regardless of the effort employed in their unit; divide the profit of the entire network.

Franchisors can use their international expansion to reinforce their success on the domestic market, that is, achieving high levels of performance (Akremi, Perrigot, \& Piot-lepetit, 2015). Based on the prominent theories of international business: the model of Uppsala (Johanson \& Vahlne, 1977), the eclectic paradigm (Dunning, 1988) and the transaction cost analysis model (Anderson \& Gatignon, 1986), this study focused on the internationalization of franchising were developed with more consistency from the early 1990's (Alon, 2006; Aydin \& Kacker, 1990; Eroglu, 1992; FladmoeLindquist \& Jacque, 1995; Goncalves \& Duarte, 1994). We must ponder the following aspect that franchises have a particularity in relation to traditional theories of internationalization and there is no way to gradually developing the internationalization. To Stanworth and Dandridge (1994) franchising is a business that consists essentially of an organization or company known as the franchisor with a business package tested on the market centered on a product or service. The franchisor through a contractual relationship relates to other companies known as franchisees often small, self-financed and selfmanaged, which will then operate under the franchisor's brand to produce and/or trade goods and services according to what is specified by the franchisor format. Franchise operations are permeated by services, this being the essence.

The internationalization of franchise studies has focused mainly on the US, Canada and Western Europe franchise networks (Doherty \& Alexander, 2004; Welsh \& Avenue-, 2006). The American market is the largest and most developed in franchising and as would be expected is also the most studied. Studies identified the countries that would be the target for the franchises (where to expand) (Eroglu, 1992; Doherty \& Alexander, 2004) and tried to understand the choice of the entry mode in foreign countries (how to expand) (Alon, 2006), in addition to the motivation for the franchise companies to expand operations abroad (why to expand) (Quinn, 1998). These studies have assumed that the decision to internationalize is part of the company's strategies.
When deciding the internationalization, the company should have some well-defined strategies, amongst them: the target market, the products and services to offer, the entry strategies into new markets, systems to control performance and risk. From this perspective, Quinn and Alexander (2002) and Aliouche and Schlentrich (2011) have proposed some models to expand franchises into international markets. Usually, in these models the authors highlight three key points: examining the target market, examining the company internal factors and choosing the best entry mode.

"Where to expand" - This is the process of identifying the countries (or regions) which are ideal to direct the operations to and the determination of which of those are priority countries (or regions) (Aliouche \& Schlentrich, 2011). The emerging markets are becoming an attractive option. There is a tendency in academic literature to focus on the attractiveness of franchises in developed countries. This is due to the fact that retail-franchising opportunities in the US are becoming saturated because of increased competition, which is not evident in emerging countries ( $\mathrm{Ni} \&$ Alon, 2010; Welsh \& Avenue-, 2006). During the identification process, companies do not always make use of wellgrounded criteria. Brazilian companies can be directed towards a country because it is the place where the investor is from. The search for foreign investors in franchising brands induces the internationalization, which often was not part of the actual strategy of the companies (Aguiar et al., 2014; Madanoglu, Alon, \& Shoham, 2017).

In contrast with the manufacturing companies, the franchising companies cannot access other markets simply through exporting. This is because they do not sell products only, the essence of many of them is to provide services and thus the product becomes only part of the operation (Lafontaine \& Leibsohn, 2005). Funds can impact "where to expand". Companies may perceive greater advantage in not leaving their home environment and simply keeping working with the structure they have, or choosing one country over another considering the investment and the return that it will provide. There is also the matter of finding ideal partners in the country of destination.

"Why to expand" - What are the reasons for the franchises to expand their business internationally? 
From this perspective, one must consider the different strategies that guide the franchise internationalization processes, which according to Quinn (1998) may be motivated by either reactive or proactive behavior. Reactive internationalization is driven by limitations of the internal market and reduced opportunities for domestic growth. In turn, proactive internationalization stems from the search for international markets even if the domestic market faces limitations.

According to Elango (2007), an explanation of the motive for the internationalization of franchises in developed countries is that the market is already saturated or the franchise model was exploited in such a way that to invest more in this market would not bring satisfactory return. Mendelsohn (1994), for example, presents a factor that may be specific and very common to the franchise sector. He states that the pressure international investors interested in entering franchises in their countries exert influence on the decision to internationalize. In a study of internationalized Brazilian companies, Aguiar, Consoni and Bernardes (2014), agreed with this assertion taking the view that most companies are directed towards internationalization by investors who contact the company aiming to introduce the brands to the countries they live in. This applies to both foreigner investors as well as Brazilians living abroad.

There is also the one proposed by Akremi et al. (2015) that expansion to reinforce their success in the domestic market.

"How to expand"- Second phase is discussion on how to expand. The methods of entry and operation in international markets compiled from the traditional literature are: (i) Franchisee-owned; (ii) Direct Franchisee; (iii) Master Franchise; (iv) Joint Venture and (v) Franchisee from a subsidiary, with own office abroad (Burton \& Cross, 1995; Quinn \& Alexander, 2002; Aliouche \& Schlentrich, 2011). Control levels and investment in the internationalization of franchises are closely linked to methods of entry into foreign markets (Jell-Ojobor \& Windsperger, 2013).

The franchise chains, when operating outside of their home country, are expected to encounter tradeoffs. If the network does not operate with a local partner - third party, presence and control are obtained through third parties, who act on the firm's behalf (Vandermerwe \& Chadwick, 1989), it can be exposed to a lack of knowledge within the host country, which will demand more investment of time and funds to adjust the process. Direct franchising, using franchisees, can exercise more control over the entire operation and this could result in better investment returns. On the other hand, they need a structure to control and train the franchise network, which affects the costs. Control over operations is total in the operation of a franchisee-owned unit in the destination country, but the amount invested in the international operation will be much higher and possibly the return provided will be less than projected. In addition, the time consumed is prohibitive. Third party strategies such as joint venture or franchise from a master franchisee can potentially only need low investment since only international operational staff needs to be trained by the network. The problem is that the returns may be less than expected as the partner of the destination country invests and must be compensated (Sanghavi, 1991). It is not only the end consumer who must be perceived as a factor responsible for profits. The distributor, in this case the agent who gets associated to the third-party franchisor, is not only a passive and facilitation agent in the sales process to the end user, but also an important customer whose business should be well constructed.

Starting in the wrong way will damage the initial strategy operation and can cause irrecoverable loss to the brand in the destination country. It can provoke a blow to the franchise image for instance. This may frustrate future expansion plans or even put an end to the internationalization project (Doherty \& Alexander, 2006).

Table 1 shows the main entry methods of franchises, key aspects and comments on the available literature of each.

\section{RESEARCH METHOD}

The research method adopted was a descriptive study based on the application of interviews and literature review. The concern in qualitative studies is to answer the question "What is happening here?" (Flick \& Gibbs, 2005) and this is exactly the purpose of this study. The focus is to provide a description of the processes studied emphasizing the strategy of companies. After analyzing a list of Brazilian franchising companies and foreign companies operating in the country, 55 were contacted. For the study we initially chose Brazilian companies who own 
Tab. 1

Modes of Franchising Operation in International Markets

\begin{tabular}{|c|c|c|c|}
\hline \multicolumn{2}{|c|}{ Operation Mode } & Key Aspects & Literature \\
\hline & $\begin{array}{r}\text { Franchisee- } \\
\text { owned }\end{array}$ & $\begin{array}{l}\text { The franchisors themselves operate a unit or } \\
\text { units outside their country. This may be the } \\
\text { option found by the networks for eventual } \\
\text { adaptations needed before starting the process } \\
\text { of selling franchises. Own Unit }\end{array}$ & $\begin{array}{l}\text { Combs and Ketchen (1999) and Alon (2006) argue that } \\
\text { this method is not the most common as having no } \\
\text { partner the network does not benefit from rapid } \\
\text { expansion at low cost, which is a precept of the } \\
\text { franchise system; On the other hand, it may be more } \\
\text { profitable. }\end{array}$ \\
\hline \multirow{2}{*}{ 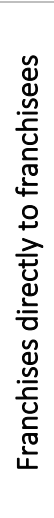 } & $\begin{array}{r}\text { Franchises } \\
\text { Directly from } \\
\text { Country of } \\
\text { Origin }\end{array}$ & $\begin{array}{l}\text { The franchisor controls the franchises from the } \\
\text { home country. There is no station or franchise } \\
\text { office in the country of destination. Low } \\
\text { investment with high risk of losing control of the } \\
\text { operation }\end{array}$ & $\begin{array}{l}\text { Common when the targets are culturally close which } \\
\text { was proved in some studies on American networks } \\
\text { operating in Canada, the United Kingdom (WEICH, } \\
\text { 1989). Brazilians also use the networks in geographically } \\
\text { distant destinations which can compromise the } \\
\text { operation }\end{array}$ \\
\hline & $\begin{array}{r}\text { Franchisee } \\
\text { from a } \\
\text { subsidiary (its } \\
\text { own office in } \\
\text { another } \\
\text { country) }\end{array}$ & $\begin{array}{l}\text { A complete new business unit is formed. The } \\
\text { proximity to the franchisee is much higher. By } \\
\text { being present in the country and play all the } \\
\text { roles inherent to a local franchiser the network } \\
\text { closely monitors the development of the } \\
\text { business and benefits from the exchange of } \\
\text { experience among the franchise agents. }\end{array}$ & $\begin{array}{l}\text { System often used by mature networks and has } \\
\text { significant operations in the country destination. } \\
\text { Although some authors consider it as a variation of } \\
\text { direct franchising system as, Cerviño and Fernandez } \\
\text { (2009) and Quinn and Alexander (2002) the cost of } \\
\text { installation must be taken into account. }\end{array}$ \\
\hline \multirow{2}{*}{ 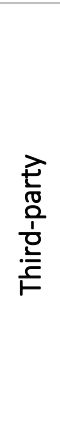 } & $\begin{array}{r}\text { Master } \\
\text { Franchising } \\
\text { (or Area } \\
\text { Franchise) }\end{array}$ & $\begin{array}{l}\text { A local operator is responsible for selling and } \\
\text { control operations in a given territory. The } \\
\text { partner must be chosen very carefully. In } \\
\text { addition to having control of the local operation, } \\
\text { the partner needs his capital compensated, so } \\
\text { the return is to divide into one more fraction. }\end{array}$ & $\begin{array}{l}\text { The master franchise may be an option (ALON, 2006) for } \\
\text { small businesses with little -known brands. The lack of } \\
\text { internal structure would not be a significant problem for } \\
\text { the company; the local partner would bear the costs. } \\
\text { Error in the choice of partner will put everything in risk } \\
\text { of losing. }\end{array}$ \\
\hline & Joint-Venture & $\begin{array}{l}\text { It is used in countries where the law requires } \\
\text { association with a local partner and in culturally } \\
\text { distant markets. This model has all the nuances } \\
\text { of a traditional society. }\end{array}$ & $\begin{array}{l}\text { The franchisor may resort to entering a new market } \\
\text { starting from a joint venture. In this case, he typically } \\
\text { establishes an association with a local business with the } \\
\text { aim of developing the area jointly (GONÇALVES; } \\
\text { MARGARIDA, 1994) }\end{array}$ \\
\hline
\end{tabular}

Source: Combs and Ketchen (1999), Alon (2001), Welch (1989), Cerviño and Fernandez (2009), Quinn and Alexander (2002), Alon (2006), Gonçalves and DuarteMargarida (1994).

or have once owned units operating abroad. Of the 42 companies interviewed, 11 questionnaires were discarded due to the lack of relevant information. After verification and validation of all data, the responses of 31 domestic companies that satisfied all chosen criteria were considered. Twenty-one foreign companies operating in the country responded to the questionnaire. For the purposes of this study the companies whose origin was in developed countries were chosen. As a result, five questionnaires were discarded resulting in a sample of 16 companies for the study.

For data collection were interviewed the directors or managers of the international expansion of Brazilian companies and the expansion directors of the international companies which operates in Brazil. The interviews were conducted in person between
2014 and 2015 at the ABF Franching Expo - the largest fair in the country and is held on a yearly basis.

The questionnaire sought information about the year of the first internationalization, the country of destination, the mode of entry used in this first experiment, if over the years this mode was changed, the current strategy of internationalization, how the company understood the aspects related to costs and control of the internationalization process.

The content analysis of the interviews was performed following the procedures of Bardin (2009) in three chronological stages, which are:

1. Pre-analyze;

2. Exploitation of material;

3. Treatment of results, inference and interpretation. 
The pre-analyze was the organization phase, the exploration of the material consisted of the most careful reading of all collected material and in the inference and interpretation phase were used basic statistics and discourse analysis of the interviews comparing patterns among the respondents based on the literature.

The data was analyzed in April 2016. All information and results have been verified and confirmed via phone and e-mails. Table 2 presents a summary of the companies studied. It shows: the country of origin; the business sector of operation; the year of the company foundation; the year when the company went international and the first country where operation took place; the entry mode used for the first international investment; if they changed or not the way they currently operate the business; the strategy that company currently uses overseas or if it has abandoned the international operation.

Tab. 2

Sample Studied

\begin{tabular}{|c|c|c|c|c|c|c|c|c|}
\hline & \multirow{2}{*}{ Country of origin } & \multirow{2}{*}{ Sector } & \multirow{2}{*}{ Foundation Year } & \multicolumn{2}{|c|}{ 1st Operation } & \multirow{2}{*}{ Entry Mode } & \multirow{2}{*}{$\begin{array}{l}\text { Change } \\
\text { Strategy }\end{array}$} & \multirow{2}{*}{$\begin{array}{c}\text { Current Operation } \\
\text { Strategy }\end{array}$} \\
\hline & & & & Year & Country & & & \\
\hline \multirow{31}{*}{ 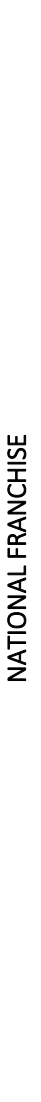 } & Brazil & Clothing & 1907 & 2007 & USA & Franchisee-owned & No & \\
\hline & Brazil & Clothing & 1949 & 2007 & USA & Franchises Directly & No & \\
\hline & Brazil & Food & 1952 & 2009 & Angola & FranchisesDirectly & No & \\
\hline & Brazil & Education & 1958 & 1985 & Argentina & Franchisee-owned & Yes & Office \\
\hline & Brazil & Education & 1961 & 1991 & USA & MasterFranchisee & No & \\
\hline & Brazil & Education & 1972 & 2010 & USA & FranchisesDirectly & No & \\
\hline & Brazil & Education & 1977 & 1989 & Portugal & Franchisee-owned & Yes & Office \\
\hline & Brazil & Food & 1981 & 2011 & USA & Franchisee-owned & Yes & Office \\
\hline & Brazil & Food & 1984 & 2008 & Paraguay & FranchisesDirectly & No & \\
\hline & Brazil & Education & 1987 & 2002 & USA & MasterFranchise & No & \\
\hline & Brazil & Food & 1987 & 2002 & Portugal & FranchisesDirectly & No & \\
\hline & Brazil & Food & 1987 & 2009 & Paraguay & FranchisesDirectly & No & \\
\hline & Brazil & Services & 1987 & 2010 & Panamá & FranchisesDirectly & No & \\
\hline & Brazil & Clothing & 1988 & 2007 & Venezuela & FranchisesDirectly & No & \\
\hline & Brazil & Services & 1989 & 2013 & Mozambique & FranchisesDirectly & No & \\
\hline & Brazil & Accessories & 1990 & 2008 & USA & FranchisesDirectly & No & \\
\hline & Brazil & Clothing & 1991 & 2004 & Peru & MasterFranchise & No & \\
\hline & Brazil & Food & 1992 & 2002 & Paraguay & FranchisesDirectly & Yes & Closed \\
\hline & Brazil & Services & 1993 & 2002 & Angola & FranchisesDirectly & No & \\
\hline & Brazil & Education & 1993 & 2006 & Angola & MasterFranchise & Yes & Office \\
\hline & Brazil & Services & 1993 & 2009 & Japan & FranchisesDirectly & No & \\
\hline & Brazil & Services & 1995 & 2005 & Argentina & FranchisesDirectly & Yes & Office \\
\hline & Brazil & Clothing & 1995 & 2014 & Italy & FranchisesDirectly & No & \\
\hline & Brazil & Services & 1997 & 2006 & Venezuela & FranchisesDirectly & No & \\
\hline & Brazil & Food & 1999 & 2004 & México & MasterFranchise & No & \\
\hline & Brazil & Accessories & 2001 & 2007 & Portugal & Joint Venture & Yes & Own Unit \\
\hline & Brazil & Accessories & 2002 & 2010 & Portugal & FranchisesDirectly & No & \\
\hline & Brazil & Accessories & 2005 & 2007 & USA & Franchisee-owned & Yes & Master \\
\hline & Brazil & Services & 2005 & 2010 & USA & FranchisesDirectly & Yes & Master \\
\hline & Brazil & Services & 2005 & 2013 & Dubai & FranchisesDirectly & No & \\
\hline & Brazil & Services & 2007 & 2010 & USA & FranchisesDirectly & No & \\
\hline \multirow{16}{*}{ 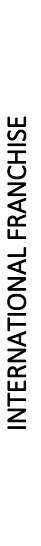 } & Austria & Accessories & 1895 & 1980 & England & Franchisee-owned & Yes & Office \\
\hline & Denmark & Accessories & 1982 & 2003 & USA & Franchisee-owned & Yes & Office \\
\hline & Spain & Food & 1979 & 1993 & Portugal & Franchisee-owned & Yes & Office \\
\hline & USA & Services & 1906 & 1960 & Canada & FranchisesDirectly & Yes & Office \\
\hline & USA & Food & 1940 & 1967 & Canada & FranchisesDirectly & Yes & Office \\
\hline & USA & Food & 1953 & 1969 & Canada & Franchisee-owned & Yes & Office \\
\hline & USA & Food & 1960 & 1983 & Canada & FranchisesDirectly & Yes & Master Franchise \\
\hline & USA & Food & 1965 & 1980 & Canada & FranchisesDirectly & Yes & Office \\
\hline & USA & Services & 1969 & 1986 & Canada & Master Franchise & No & \\
\hline & USA & Services & 1988 & 1992 & England & Franchisee-owned & Yes & Office \\
\hline & USA & Services & 1991 & 2009 & South Korea & FranchisesDirectly & Yes & Master Franchise \\
\hline & USA & Services & 2000 & 2005 & Canada & FranchisesDirectly & Yes & Master Franchise \\
\hline & France & Personal Care & 1976 & 1996 & USA & FranchisesDirectly & Yes & Office \\
\hline & Portugal & Services & 1986 & 1990 & Poland & Franchisee-owned & Yes & Office \\
\hline & Portugal & Clothing & 2004 & 2014 & Brazil & FranchisesDirectly & Yes & Office \\
\hline & Switzerland & Food & 2007 & 2011 & Brazil & Master Franchise & No & \\
\hline
\end{tabular}

Source: Prepared by the authors based on Barney \& Clark, 2007. 


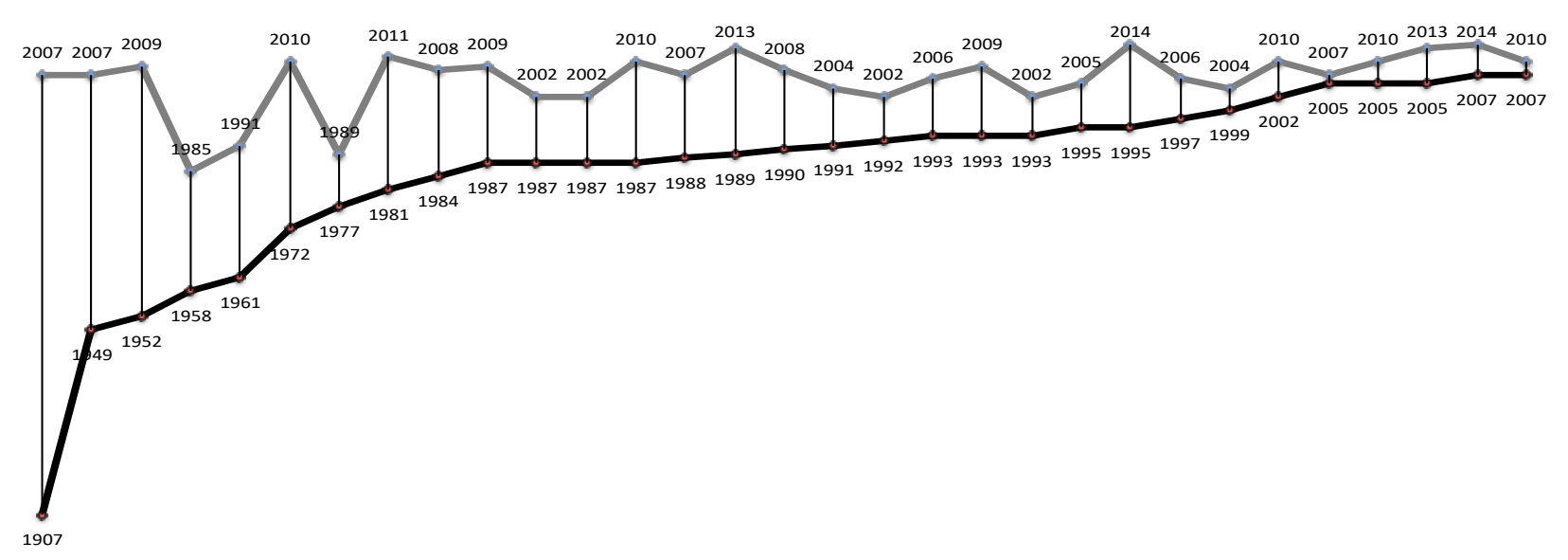

Fig. 1

Foundation Year $x$ Year of the Internationalization of Brazilian Franchises

Source: Authors

Sample considerations - The companies surveyed, both Brazilian and international have at least 50 successful operations in their local markets. These companies present significant differences when analyzed taking into consideration the year of internationalization and foundation.

Figures 1 and 2 show the year of the businesses foundation versus the year of the internationalization of the analyzed sample, regardless of whether they were or not in franchising activities at the time.

Figure1 shows that recently the process of internationalization of Brazilian companies of the sample has become faster. Taking into account all the companies the average period for internationalization is 21 years. When analyzing the internationalization excluding the three outliers companies it is 15.5 years on average.
In the analyzed sample, International companies averaged 21 years of internationalization. Brazilian companies in the sample, excluding the two outliers, had 16 years on average of internationalization. Comparing average of foundation dates of international and domestic companies, this showed that international companies are older.

Figure 3 represents a summary of figure 2 and 3 showing that the average period for internationalization of international companies with year of foundation (1968) and year of internationalization (1989), and for Brazilian companies with year of foundation (1985) and year of internationalization (2005).

As can be seen and had already appeared in studies presented in the literature review developed countries have numerical advantage in years of

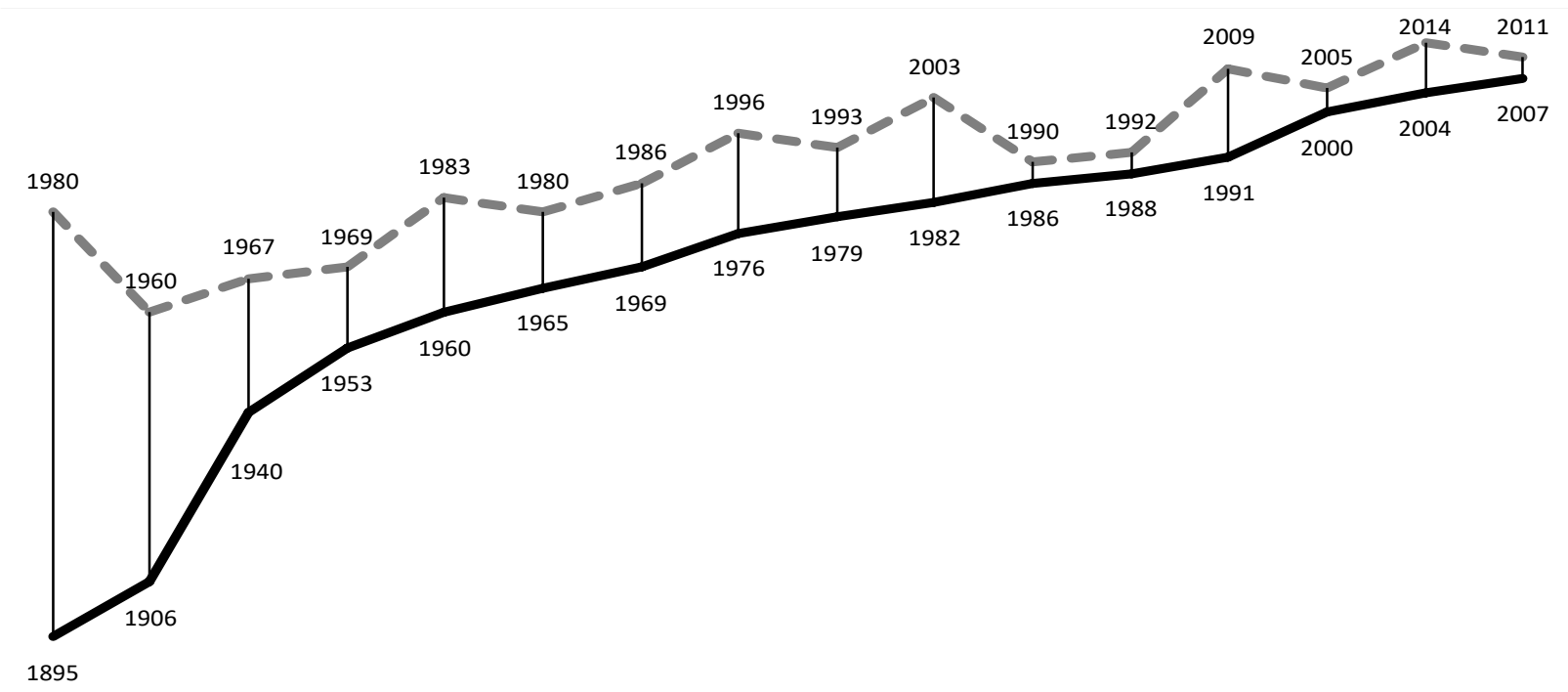

Fig. 2

Foundation Year x Year of the Internationalization of International Franchises operating in Brazil Source: Authors 


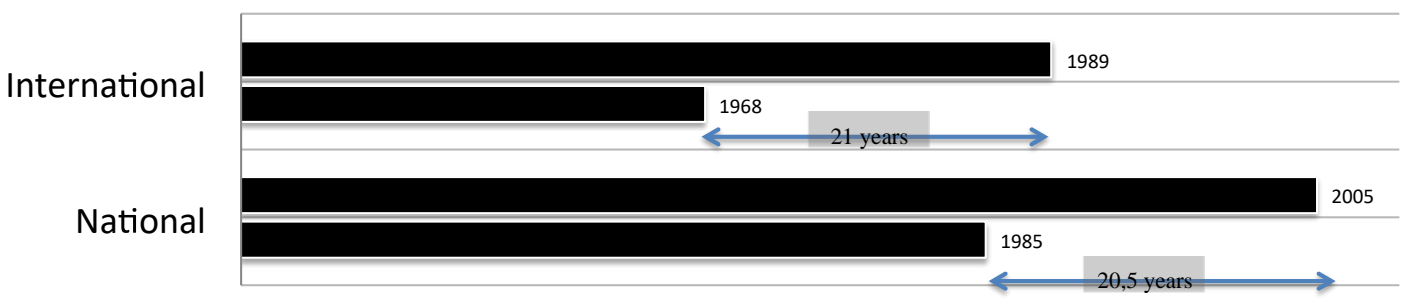

Fig. 3

Average Compared to Year of Internationalization and Foundation

Source: Authors

internationalization, but on average they do not show greater speed when seeking new internationalization. Figure 3 also shows that foreign brands started their international operations 17 years (1968) before the Brazilian ones, which, although not validated statistically, may be a factor that influenced the way they operate.

\section{FINDINGS AND DISCUSSION}

For 30 percent of the sample of Brazilian companies, the method of operation has not changed since the time they became internationalized. Amongst international companies only 12 percent keep operating as they did initially. Table 3 explains the operating modes acknowledged by respondents and their perceptions about control and investment. The following is a compilation of perceptions concerning each operation mode.

Franchisee-Owned - Where franchisors test their concepts and adjust the method of operation for new franchisees. According to most respondents, it is not a long-term strategic option as the business purpose of these companies is to sell franchises and not operate them, as seen in Alon (2006). Acording to Combs and Ketchen (1999) and Alon (2006) this is a method that does not take advantage of rapid expansion at low cost, which is a franchising system precept. On the other hand, it may be the most profitable. As the control in this case is high, international companies have reported, as shown in the theories, that the operation investment level was high, but the control was clearly exercised. No problems with franchisees would happen at the beginning of operations, since they were not part of the business at that time.

Franchises directly (from the country of origin) This is often the preferred option of domestic companies starting out in the internationalization process. This mode of operation can be extremely profitable in the short term. Franchisors invest little cash. In the long term, the brand image can be affected, if defined operational patterns are not followed. Among the international companies that opted to franchise directly from the country of origin, only two brands, in contrast to Brazilian companies, did not do so in countries geographically nearby. In this case, American franchising companies operating in Canada, as pointed out in Welch (1989) studies (1989) and Burton and Cross (1995).

Master Franchise and Joint Venture - In the franchise called "Third-party", the dependence on local partner is large. When this partner understands the business and the organizational culture combines these aspects with good relationships and good information flow, this method can be an attractive option for development in foreign markets. Usually the master franchisee absorbs part of the costs, which makes operational investment lower. If a jointventure agreement occurs, the initial cost can be shared between the partners. Thus, it does not become a high investment. Both third-party agreements (Master Franchise and Joint Venture) bring a distinctive element frequently out of scope of the existing literature. According to respondents, these operating modes experience influence on the Third Party, so the franchise in actuality is not always exactly the one envisaged by the country of origin. This study does not intend to characterize all these nuances. Subsidiary - Internationalized franchises from developed countries of the sample predominantly use a subsidiary (Burton \& Cross, 1995). That seems to be the trend in franchising companies. To the managers interviewed, despite the initial cost, this operating mode is what ensures greater control in foreign operations. With the maturing of the operation, financial costs can be diluted. Problems that may occur, such as loss of franchise identity, are avoided in this mode. Unlike the directly from the country of origin mode of franchise where there is no third-party too, being close and controlling the operation prevents small 
Tab. 3

Summary of Entry Methods, Control and Investment Levels

\begin{tabular}{|c|c|c|c|}
\hline Operation Mode & Description & Control & Investment \\
\hline Franchisee-owned & $\begin{array}{l}\text { No partner, associate or any barrier between the company and the } \\
\text { operation, the entire culture can be transferred without interference. } \\
\text { Despite the cost, international companies in the sample indicated this } \\
\text { as the most effective to start an operation in a new market. }\end{array}$ & High & $\begin{array}{l}\text { High } \\
\text { ON ANY SCALE }\end{array}$ \\
\hline $\begin{array}{r}\text { Franchises directly } \\
\text { (from the country of } \\
\text { origin) }\end{array}$ & $\begin{array}{l}\text { The control of the operation, without a constant consulting company } \\
\text { on site, can affect the uniformity and the operation; domestic firms } \\
\text { reported cases ranging from changing menu of products, advertising } \\
\text { not aligned with the headquarters and even communication problems. }\end{array}$ & Low & $\begin{array}{l}\text { LOW } \\
\text { ON ANY SCALE }\end{array}$ \\
\hline $\begin{array}{r}\text { Master Franchising or } \\
\text { Area Franchise }\end{array}$ & $\begin{array}{l}\text { Costs and investment in this method must be taken into account, } \\
\text { depending on the number of units may become impractical. Keeping } \\
\text { an entire system for sale and control with low financial results may not } \\
\text { be feasible at first and may even lead to the closing of the transaction } \\
\text { in the destination country. However, when the operation is mature, } \\
\text { this is the method pointed out as a natural evolution for international } \\
\text { franchise networks. }\end{array}$ & Medium & $\begin{array}{l}\text { LOW } \\
\text { ON ANY SCALE }\end{array}$ \\
\hline Joint venture & $\begin{array}{l}\text { The local partner, with whom the company will share operation } \\
\text { control, is one key element. Some respondents even reported the end } \\
\text { of an operation due to wrong choice of overseas partner. }\end{array}$ & Medium & $\begin{array}{l}\text { Medium } \\
\text { ON LOW SCALE } \\
\text { LOW } \\
\text { ON HIGH SCALE }\end{array}$ \\
\hline $\begin{array}{r}\text { Direct franchisee } \\
\text { from a subsidiary, its } \\
\text { own office in another } \\
\text { country }\end{array}$ & $\begin{array}{l}\text { The joint venture agreement is generally used in countries with very } \\
\text { complex legislation where a local partner can make a difference. In the } \\
\text { case of the sample, the only company that used this method had an } \\
\text { agreement between close relatives. }\end{array}$ & High & $\begin{array}{l}\text { High } \\
\text { INITIALLY LOW SCALE } \\
\text { LOW } \\
\text { ON HIGH SCALE }\end{array}$ \\
\hline
\end{tabular}

Source: Authors

deviations of conduct by franchisees and improves the perception of the local market.

Figure 4 shows the relationship between franchisor and franchisees or third party, the nuances of the changes that these relationships provoke and their main positive and negative impacts. In franchisee-owned mode, as the franchisor owns the company there are no communication problems, but it excludes the benefit of raising third-party funds. In franchises directly (from the country of origin), the franchise does not suffer from the influence of others, but without effective control it may lose uniformity. Respondents were emphatic in stating that the presence of a third party changes the business whether a master or a joint venture agreement. These changes can cause benefit or cause damage to the franchise structure in the country. Thus, choosing the right partner is key to the international operation. Franchise from a subsidiary requires a group highly aligned with the company of origin.

With the learning acquired selling units seemed natural in a business where success will guarantee. An office operating as subsidiary was the chosen strategy by many respondents. One example is a respondent who has over 40,000 points of sale around the world and in the words of its International Director "... it would be impossible to operate so many stores, so many different cultures without an advanced post in those countries. However much the media are very advanced, living the reality of the place in day-to-day is different and brings countless benefits for the company."

In another case the Marketing Director of a large international cosmetics company went further, "... we have fixed, in different way, the organizational culture. Our local office is a natural extension of the company with the difference that here everybody speaks Portuguese and understands the demands of local franchisees, legislation and economic environment. This helps us to understand each country and once we are a company department, the headquarters receives the information without interference. The company uses an office with people trained in its headquarters." In her view, it would be very difficult that a partner alone could pass on completely the culture and the essence of the company. As the Brazilian subsidiary is an extension of headquarters the information exchange occurs naturally. A third party, be it master franchisee or 


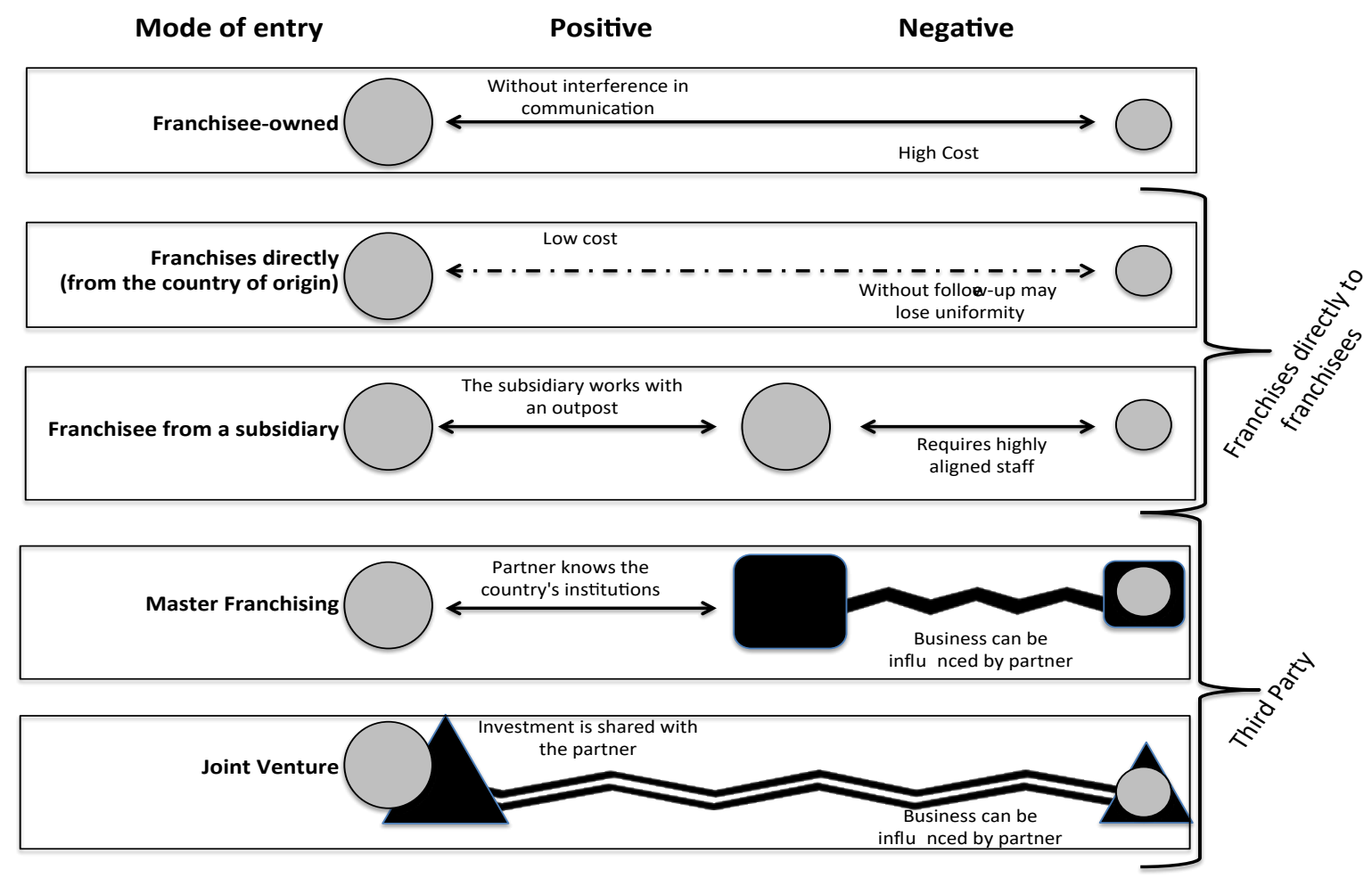

Fig. 4

Positive and Negative Points in Operation Modes

Source: Authors

partner (joint venture), is also a customer and would bring in another influence via its own operation and system.

Brazilian companies, as already mentioned, often use the franchise direct method in its first internationalization attempt and suffer a number of problems. The lack of operational control without a constant consulting company on site can affect the uniformity and the operation. Companies reported various disappointing outcomes with regard to this way of operating.

One Brazilian company operating in a geographically near market but without a proper structure for the country had problems with control. In this case, the franchisee as reported by the network expansion manager thought that his seafood restaurant franchisee could also sell "barbecue". As this franchisor did not have a field consultant to carry out periodic visits to the operation, it took a while until the headquarters could discover what was going on.

Despite the problems when asked why Brazilian companies do not change the way they operate in such a market most reported that internationalization is not a primary strategy of companies. Many simply regard the operation as a laboratory to verify from this experiment if the brand has potential for internationalization to be further developed in future. Rocha et al. (2014) demonstrated that most of the internationalized Brazilian franchises are in the experimental stage, leading to minimal involvement.

However, international companies see internationalization as a key strategy within its portfolio of options, considering that in their countries there are no simple opportunities for steady and robust growth. Having a subsidiary in the destination countries seems to be a natural evolution and satisfy a need for consolidated companies.

One of the latest Brazilian franchises to internationalize, already relying on information and guidance, chose to settle directly with an office fully formed in the destination country. This office is responsible for the opening of the first units of the brand and when the operation becomes strong enough, it will be parent of new units that will be sold to franchisees. This movement according to its manager's information will bring greater control of the network overseas. 
Tab. 4

Sample Current Operation

\begin{tabular}{lccccc}
\hline \multicolumn{1}{c}{ Origin } & Franchisee-owned & Franchises-directly & Master Franchising & Joint- Venture & Subsidiary \\
\hline Brazil & 6 & 58 & 19 & 0 & 16 \\
International & 0 & 0 & 31 & 0 & 69 \\
\hline
\end{tabular}

Source: Authors

This undertaking, even after being subsidized initially by the Brazilian government, was only made possible by a large investment in the brand. According to one of the managers "Due to the fact that the company had already considerable structure in the domestic market and financial health, it could choose this strategy for its first internationalization." Table 4 summarizes the current operating mode of Brazilian and international franchises by percentage.

Table 4 shows that the Brazilian companies in the sample use various methods of operation in their international expansion strategy. This shows that despite the fact that they seek internationalization, they are still in a development stage, as seen In Camargo, Rocha and Silva (2016).

The Master Franchising and Subsidiary methods were the only ones found in the sample in international franchises. Based on this result, both from the respondents reports and on data, the longest average operation time in foreign markets, 24 years in the sample for international franchises and eight years for Brazilian franchises, it seems that the companies not only seek greater control but also the reduction of the risk capital employed when internationalizing.

\section{CONCLUSIONS, LIMITATIONS AND FUTURE RESEARCH}

The study sought to understand whether there are significant differences between franchisors of developed and emerging countries when operating in international markets. The results showed that franchisors from developed countries prefer to use a subsidiary in the destination country. The subsidiary method in each target country, little studied in academic circles, proved to be the most used by franchisors for developed countries (69 percent). It seems to be a natural evolution in order to enter and operate a franchised network. Although little used by Brazilian franchisors (16 percent), it is the method of operation used by the two Brazilian companies that longer operate overseas. As a second choice, foreigner companies (31 percent) use master franchisees. It is also little used by Brazilian companies (19 percent). Foreign companies ignore stores and direct franchises, which is the preferred method of Brazilian franchisors (58 percent).

The internationalization maturation of the franchises in developed countries be it by the experience that comes with passage of time or due to volume increase in foreign operations, culminate in the search for strategies that would provide greater control of the operation. Other factors also affect the business. For example, the geographic distance causing disfigurement of the business due to the lack of close monitoring. Simple franchising from the country of origin with little control should advance to next level.

Creating a subsidiary of the franchisor to act as an advanced post in the operation at the destination country with communication without interference has high initial cost, but this is diluted as the network increases. Directors of international franchises recommend this as the safest way to keep control and achieve solid growth using one of the principles of the franchise, third-party capital. This method, equipped with personnel aligned with the company of origin, brings the core of what is franchise, a proven and standardized business even if it is remote from the home country. Of course, each country has peculiarities and adaptation is mandatory in the operations and sometimes even in the products, but uniformity is one of the pillars of the system. Without it one more of the attractions of the franchise is lost.

The fact is that most of the studied Brazilian companies are only beginning their internationalization experiences and use methods to prospect foreigner markets without large investments. They claim not to be able to afford more expensive methods, but they risk losing control of the expansion and its outcomes in the target markets. The opportunity to study consolidated operations versus more recent entry operations reveals the gap between the beginning of the process and mature operations. In the study, it is clear that the entry strategies of Brazilian franchisors are still at an 
experimental stage as seen in on Rocha et al. (2014). Many are not ready to safely increase the number of units overseas and ensure control over their operations. Returning to the question that has guided this study it is concluded that foreign franchisors in Brazil clearly evidence a more mature level than the Brazilian companies that go abroad. The foreign companies have clarity concerning the importance of a close control over the operations, which is reflected in their preference for the more engaged models of entry and operation. A clear limitation of this study lies in the number of international companies that responded to the survey.

The subject discussed here, the evolution of the way of operating in the foreign market by franchises, is still relatively little studied, raises questions and opens space and needs future studies. For the management of franchisors, this paper points out that the subsidiary is a natural evolution of entry and operation mode when it is desired or it is needed to control the expansion of networks in other countries. Thus, managers of franchisors in emerging countries should carefully examine the subsidiary option in the target country when their company considers accelerating international growth.

\section{REFERENCES}

- Associação Brasileira De Franchising - ABF. (2017) Evolução do Setor 2003-2014. Retrieved September, 2017, from http://www.abf.com.br/wpcontent/uploads/2017/06/Desempenho-doFranchising-2016-Internacionalizacao-2.pdf

- Aguiar, H. de S., Consoni, F. I., \& Bernardes, R. C. (2014). Estratégia de internacionalização conduzida: um estudo em Redes de Franquias Brasileiras. RECADM- Revista Eletrônica de Ciência Administrativa, 13(1), 114-131. http://doi.org/10.5329/RECADM.2014002

- $\quad$ Aguiar, H. de S., Consoni, F. L., \& Bernardes, R. C. (2014). Redes de Franquia Brasileiras Internacionalizadas : evolução do método de entrada no. Revista Ibero-Americana de Estratégia - RIAE, 13(1), 33-48. http://doi.org/10.5585/riae.v13i1.1985

- $\quad$ Akremi, E., Perrigot, R., \& Piot-lepetit, I. (2015). Examining the Drivers for Franchised Chains Performance through the Lens of the Dynamic Capabilities Approach *. Journal of Small Business Management, 53(1), 145-165. http://doi.org/10.1111/jsbm.12059

- Aliouche, E. H., \& Schlentrich, U. a. (2011). Towards a Strategic Model of Global Franchise Expansion. Journal of Retailing, 87(3), 345-365.

http://doi.org/10.1016/j.jretai.2011.01.004
- Alon, I. (2006). Market Conditions Favoring Master International Franchising. Multinational Business Review, 14(2), 67-82.

- $\quad$ Anderson, E., \& Gatignon, H. (1986). Modes of Foreign Entry: A Transaction Cost Analysis and Propositions. Journal of International Business Studies, 17(3), 1-26. http://doi.org/10.1057/palgrave.jibs.8490432

- $\quad$ Aydin, N., \& Kacker, M. (1990). International Outlook of US-based Franchisers. International Marketing Review, 7(2). http://doi.org/10.1108/02651339010143381

- Baena, V. (2012). Market conditions driving international franchising in emerging markets. International Journal of Emerging Markets, 7(1), 49-71. http://doi.org/10.1108/17468801211197879

- Baena Graciá, V., \& Cerviño Fernández, J. (2009). La internalización de la franquicia española y sus formas de penetración de mercados. Cuadernos de Economía y Dirección de la Empresa, 12(40), 47-82. http://doi.org/10.1016/S1138-5758(09)70042-8

- Bardin, L. (2009). Análise de conteúdo (Edição revista e actualizada). Lisboa: Edições 70.

- Brookes, M., \& Roper, A. (2011). International master franchise agreements: An investigation of control from operational, relational and evolutionary perspectives. European Journal of Marketing, 45(7/8), 1253-1276. http://doi.org/10.1108/03090561111137705

- Burton, F. N., \& Cross, A. R. (1995). Franchising and foreign market entry. In International marketing reader (p. 35-48). London: Routledge.

- Camargo, M. A. de A. P., Rocha, T. V., \& Silva, S. C. e. (2016). Estratégias de marketing no processo de internacionalização de franquias brasileiras. Revista Brasileira de Gestão de Negócios, 18(62), 570-592. http://doi.org/10.7819/rbgn.v18i62.2804

- Combs, J. G., \& Ketchen, D. J. (1999). Can capital scarcity help agency theory explain franchising? Revisiting the capital scarcity hypothesis. Academy of Management Journal, 42(2), 196-207. http://doi.org/10.2307/257092

- Doherty, a M., \& Alexander, N. S. (2004). Relationship development in international retail franchising: case study evidence from the UK fashion sector. European Journal of Marketing Relationship, 38(9/10), 12151235. http://doi.org/10.1108/03090560410548942

- Doherty, a M., \& Alexander, N. S. (2006). Power and control in international retail franchising. European Journal of Marketing, 40(11/12), 1292-1316. http://doi.org/10.1108/03090560610702821

- Dunning, J. H. (1988). The Eclectic Paradigm of International Production: A Restatement and Some Possible Extensions. Journal of International Business Studies, 19(1), 1-31 http://doi.org/10.1057/palgrave.jibs.8490372

- Elango, B. (2007). Are Franchisors with International Operations Different from Those Who Are Domestic Market Oriented? Journal of Small Business 
Management, 45(2), 179-193. Recuperado de http://onlinelibrary.wiley.com/doi/10.1111/j.1540627X.2007.00208.x/full

- Eroglu, S. (1992). The Internationalization Process of Franchise Systems: A Conceptual Model. International Marketing Review. http://doi.org/10.1108/02651339210020277

- $\quad$ Fladmoe-Lindquist, K., \& Jacque, L. (1995). Control modes in international service operations: The Propensity to Franchise. Management Science, 41(7), 1238. Recuperado de http://pubsonline.informs.org/doi/abs/10.1287/mnsc.4 1.7.1238

- Flick, U., \& Gibbs, G. (2005). Análise de dados qualitativos. Análise de dados qualitativos. Porto Alegre: Bookman.

- Goncalves, V. F. C., \& Duarte, M. M. M. C. (1994). Some Aspects of Franchising in Portugal. International Journal of Retail \& Distribution Management, 22(7), 30-40.

- Gonzalez-diaz, M., \& Solis-rodriguez, V. (2012). Journal of Business Venturing Why do entrepreneurs use franchising as a fi nancial tool? An agency explanation. Journal of Business Venturing, 27(3), 325-341. http://doi.org/10.1016/j.jbusvent.2011.03.001

- Hackett, D. (1976). The international expansion of US franchise systems: status and strategies. Journal of International Business Studies, 7(1), 65-75. Recuperado de http://www.palgravejournals.com/jibs/journal/v7/n1/abs/8490883a.html

- Jell-ojobor, M., \& Windsperger, J. (2013). Journal of International Management. The Choice of Governance Modes of International Franchise Firms Development of an Integrative Model. Journal of International Management.

- Jensen, M. C., \& Meckling, W. H. (1976). Theory of the firm: Managerial behavior, agency costs and ownership structure. Journal of Financial Economics, 3(4), 305360. http://doi.org/10.1016/0304-405X(76)90026-X

- Johanson, J., \& Vahlne, J. (1977). Process of The Internationalization Development Firm-A Model of Knowledge Foreign and Increasing Market Commitments. Journal of international business studies, 8, 23-32.

- Khanna, T., \& Palepu, K. G. (2010). Winning in the World's Emerging Markets, 2nd Edition. Harvard Business Review.

- Khauaja, D. M. R., \& Toledo, G. L. (2011). O processo de internacionalização de empresas brasileiras: Estudo com franqueadoras. Internext - Revista Eletrônica de Negócios Internacionais, 6(1), 42-62.

- Lafontaine, F. (1992). Agency Theory and Franchising: Some Empirical Results. The RAND Journal of Economics, 23(2), 263-283. http://doi.org/10.2307/2555988

- Lafontaine, F., \& Leibsohn, D. (2005). Beyond Entry: Examining McDonald 's Expansion in International
Markets. In in International Society of Franchising Conference Proceedings (p. 0-26).

- Madanoglu, M., Alon, I., \& Shoham, A. (2017). Push and pull factors in international franchising factors. International Marketing Review, 34(1), 29-45. http://doi.org/10.1108/IMR-03-2015-0037

- Melo, P. L. de R., Borini, F. M., Oliveira Jr., M. D. M., \& Parente, R. C. (2015). Internationalization of Brazilian Franchise Chains: A Comparative Study. RAE - Revista de Administração de Empresas, 55(3), 258-272.

- Mendelsohn, M. (1994). A essência do franchising. (ABF-Associação Brasileira de Franchising, Org.). São Paulo.

- Ni, L., \& Alon, I. (2010). U.S.-Based Fast-Food Restaurants: Factors Influencing the International Expansion of Franchise Systems. Journal of Marketing Channels, 17(4), 339-359. http://doi.org/10.1080/1046669X.2010.512861

- Quinn, B. (1998). Towards a framework for the study of franchising as an operating mode for international retail companies. The International Review of Retail, Distribution and Consumer Research, 8(4), 445-467. http://doi.org/10.1080/095939698342751

- Quinn, B., \& Alexander, N. (2002). International retail franchising: a conceptual framework. International Journal of Retail \& Distribution Management, 30(5), 264-276. http://doi.org/10.1108/09590550210426426

- Rocha, T., Borini, F., \& Spers, E. (2012). Aspectos mercadológicos e estratégicos da internacionalização das franquias brasileiras (Vol. 2). São Paulo: ESPM.

- Sanghavi, N. (1991). Retail franchising as a growth strategy for the 1990s. International Journal of Retail \& Distribution Management, 19(2).

- $\quad$ Stanworth, J., \& Dandridge, T. (1994). Business franchising and economic change: an overview. International Small Business Journal, 12(2), 12-14.

- Thomas, D. (2013). Internationalization of franchises from emerging markets: a focus on Latin-America. International Journal of Business Strategy, 13(1), 13.

- Vandermerwe, S., \& Chadwick, M. (1989). The Internationalisation of Services. The Service Industries Journal, 9(1), 79-93. http://doi.org/10.1080/02642068900000005

- Welch, L. S. (1989). Diffusion of Franchise System Use in International Operations. International Marketing Review, 6(5), 7-19. http://doi.org/10.1108/EUM0000000001520

- Welsh, D. H. B., Alon, I., \& Falbe, C. M. (2006). An examination of international retail franchising in emerging markets. Journal of Small Business Management, 44(1), 130-149. http://doi.org/10.1111/j.1540-627X.2006.00158.x

- Welsh, D. H. B., \& Avenue-, H. (2006). An examination of international retail franchising in emerging markets James W. Walter Distinguished Chair in Entrepreneurship Professor of Management Director , Entrepreneurship \& Family Business Programs Sykes College of Business University of Tampa 40, 4958(January). 


\section{ABOUT THE AUTHORS}

- Helder de Souza Aguiar holds Master's Degree of Science from the Business School at the Centro Universitário da FEI (FEI-SP). Doctorate student in Business Administration from the Business School Also is professor at Universidade Anhembi Morumbi. Email: helderaguiar@usp.br

- Marcos Roberto Luppe holds Doctor of Philosophy from the School of Economics, Business Administration and Accounting at the Universidade de São Paulo (USP). Also, is professor at EACH in Universidade de São Paulo (USP). Email: mluppe@usp.br

- Paulo Tromboni de Souza Nascimento holds a doctor of Philosophy from the School of Economics, Business Administration and Accounting at the Universidade de São Paulo - FEA/USP, São Paulo, SP, Brazil. Also is associate professor at FEA/USP.Email: tromboni@usp.br 


\title{
Franquiadores Brasileiros: Entrada e Operação de Franquias Internacionalizadas
}

\author{
Helder de Souza Aguiar ${ }^{A}$, Marcos Roberto Luppe ${ }^{B}$ e Paulo Tromboni de Souza Nascimento ${ }^{B}$ \\ ${ }^{A}$ Universidade Anhembi Morumbi - UAM, São Paulo, SP, Brasil \\ ${ }^{B}$ School of Arts, Sciences and Humanities, University of São Paulo - EACH/USP, São Paulo, SP, Brasil
}

\begin{tabular}{l}
\hline DETALHES DO ARTIGO \\
\hline Histórico do artigo: \\
Recebido: 28 de fevereiro de 2017 \\
Aceito: 03 de outubro de 2017 \\
Disponível online: 11 de novembro de 2017 \\
Sistema de Revisão "Double Blind Review" \\
Editor científico: \\
Mariana Sutter
\end{tabular}

\section{Palavras-chaves:}

Franchising

International Operation

Entry Mode

Franchisors

Internationalization

\begin{abstract}
RESUMO
Este estudo teve como objetivo comparar as estratégias de entrada e operações dos franqueadores de países desenvolvidos em países estrangeiros com contrapartes brasileiras. Existem diferenças significativas? Foi realizado um estudo exploratório com 16 franqueadores internacionais que operam no Brasil e 31 franqueadores brasileiros que operam no exterior. Os resultados mostram que os franqueadores internacionais que operam no exterior preferem usar uma subsidiária no país de destino. Ao mesmo tempo, esta estratégia é pouco utilizada pelos franqueadores brasileiros, que preferem a estratégia de franquias diretas. Para a coleta de dados, foram entrevistados 47 diretores ou gerentes de expansão internacional de empresas brasileiras e os diretores de expansão das empresas internacionais que operam no Brasil. Embora mais caro, a subsidiária no país alvo oferece maior controle sobre a expansão dos negócios, reduzindo os problemas causados pela distância do país de origem. Para o gerenciamento de franqueadores, este artigo aponta que a subsidiária é uma evolução natural do modo de entrada e operação quando é desejada ou é necessária para controlar a expansão das redes em outros países. Assim, os gerentes de franqueadores em países emergentes devem examinar cuidadosamente as opções da subsidiária no país alvo quando sua empresa considera acelerar o crescimento internacional.
\end{abstract}

C 2017 Internext | ESPM. Todos os direitos reservados!

To cite this article:

Aguiar, H. S., Luppe, M. R, and Nascimento, P. T. S. (2017). Brazilian franchisor: Entry and operation of internationalized franchise. Internext - Review of International Business, 12 (3), 16-30. DOI:

http://dx.doi.org/10.18568/1980-4865.12316-30

To access this article: $h t t p: / / d x$. doi.org/10.18568/1980-4865.12316-30 